\title{
Reflection
}

\section{Archaeological Treasures of Dolenjski muzej Novo mesto}

\section{Stipančić P ${ }^{1}$, Dokl-Osolnik J ${ }^{1}$}

1. Dolenjski muzej Novo mesto, Slovenia

* Correspondence: Petra Stipančič petra.stipancic@dolenjskimuzej.si, Jasna Dokl Osolnik jasna.dokl.osolnik@dolenjskimuzej.si

Citation: Stipančić P, Dokl Osolnik J. Archaeological treasures of Dolenjski muzej Novo mesto. Proceedings of Socratic Lectures. 2021; 6: 157-163. https://doi.org/10.55295/PSL.2021.D. 020

Publisher's Note: UL ZF stays neutral with regard to jurisdictional claims in published maps and institutional affiliations.

\begin{abstract}
:
Dolenjski muzej Novo mesto takes care of very rich cultural heritage. Even since the beginning, Dolenjski muzej has been best known for its permanent archaeological exhibition. A short overview of enormous, very prestige archaeological heritage is presented with special effort on the Early Iron Age.
\end{abstract}

Keywords: Dolenjski muzej Novo mesto; Archaeology; Prehistory; Early Iron Age

\section{(c) (i)}

Copyright: (C) 2021 by the authors. Submitted for possible open access publication under the terms and conditions of the Creative Commons Attribution (CC BY) license

(https://creativecommons.org/licenses/b $\mathrm{y} / 4.0 /)$. 


\section{Geographical position of Novo mesto}

Slovenia is a Central European Country with two million inhabitants, bordered by Italy in the west, Austria in the north, Hungary in the northeast and Croatia in the east and south. It lies at the point where the Alps, the Mediterranean, the Pannonian Plain and the Dinaric Alps meet. The diversity of its geographical features in the past fostered human endeavour, dwelling, commerce and the adoption of cultures from neighbours near and far.

The highly distinctive landscape of the Dolenjska region lies in the south-eastern part of Slovenia, and is centred around Novo mesto, which has around 25,000 residents and plays an important commercial, cultural and educational role not just in the region, but also further afield (Figures 1, 2).

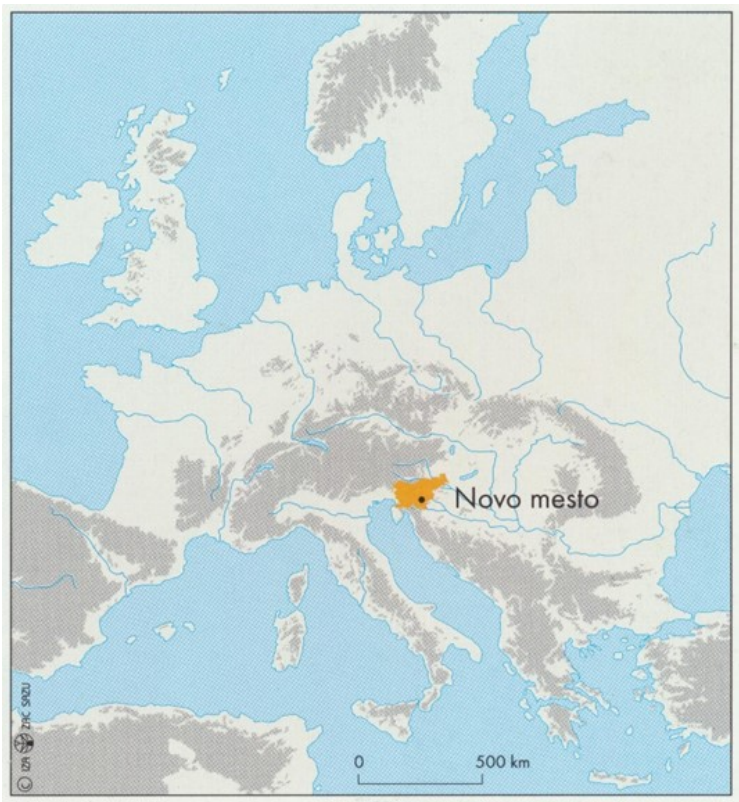

Figure 1. Position of Slovenia and Novo mesto.

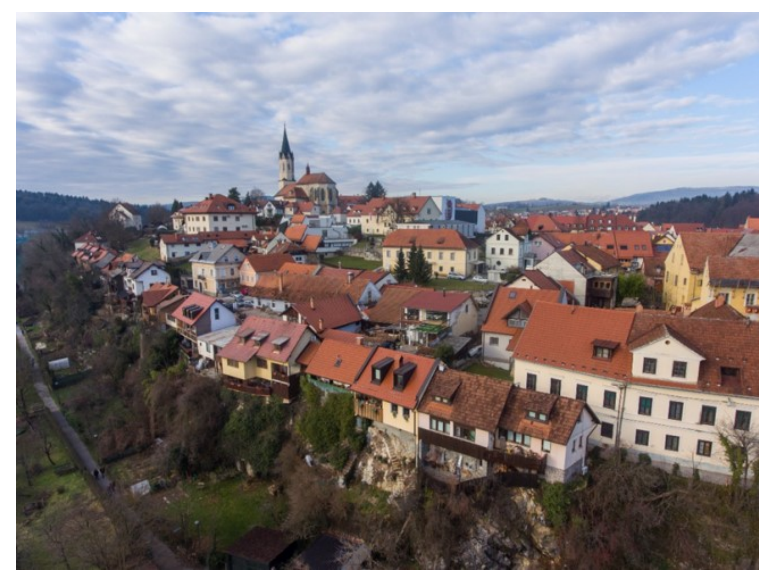

Figure 2. Novo mesto as town was established in 14th century but archaeological evidences of first human presence are much older. 


\section{Dolenjski muzej Novo mesto and Archaeology}

Dolenjski muzej Novo mesto was founded on 1 June 1950, and is a museum of regional type with archaeological, ethnological, cultural history and art history departments, a department for contemporary history and an education department, along with two separate units, the Jakčev Dom (an artist's collection) and the Kočevski Rog (World War II sites) (Figure 3).

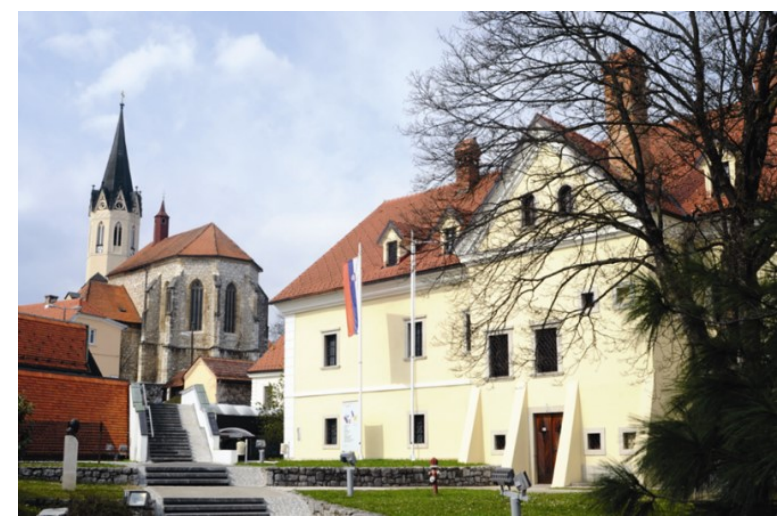

Figure 3. View on the Dolenjski muzej Novo mesto.

The first permanent archaeological exhibition was set up by staff at Dolenjski muzej in 1953, with material that was borrowed from private collections. Tone Knez, the first archaeologist at the museum, set up the first permanent archaeological exhibition in 1983, displaying material collected by the museum through its intensive and multiple archaeological research projects throughout Dolenjska, especially in Novo mesto. Even when the museum opened the space for the permanent exhibition was too cramped for all the exhibits, so the majority of the material stayed stored in repositories.

Evidence of the first settlement or use of the physical space in the area of Novo mesto dates back to the 6th-5th millennium BC. The settlement pattern begins to change in the Late Bronze Age (9th century BC) and reaches a high point in the Early Iron Age (8th to 4th centuries BC). The Early Iron Age is the period of Greek culture in the Mediterranean, with the flourishing of city states contrasting with what contemporary Greeks saw as 'Barbarian' Europe. The Early Iron Age or Hallstatt culture, named after the archaeological site of Hallstatt in Austria, is subdivided geographically, and Slovenia was a part of its south-eastern sub-Alpine area.

The Dolenjska Hallstatt group plays a central role in Slovenia with its wealth of archaeological sites, including Novo mesto. One of the most important economic sectors of the Early Iron Age in Dolenjska was ironworking, which allowed the extraordinary development and flourishing of all of society. Iron ore in the form of lumps of manganese-rich limonite lies on the surface and was easily accessible (Figure 4). The iron ore was worked into iron products which were traded. Despite the lack of written sources, we can study and familiarise ourselves with this extraordinarily interesting and important period for our ancestors, by studying the rich and exceptional archaeological material heritage kept at the Dolenjski muzej. 


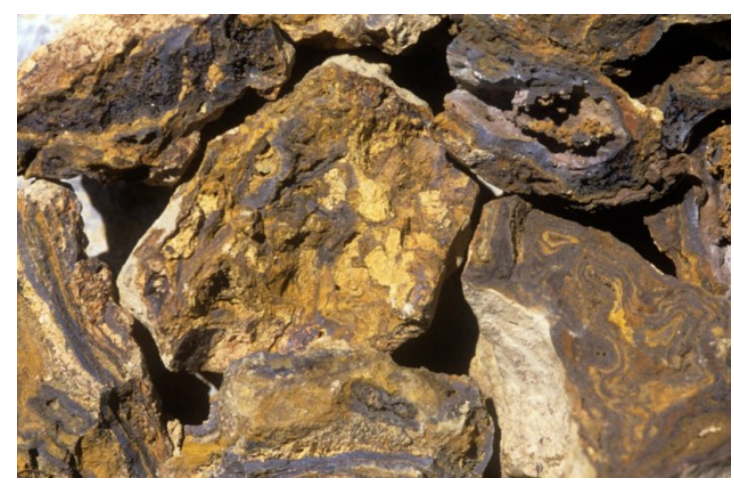

Figure 4. The most important raw material in the Iron Age was iron ore.

\section{Archaeological Image of Dolenjska}

Since 2008, a new permanent exhibition on the "Archaeological Image of Dolenjska" has been on display. It was created by museum archaeology curator Borut Križ and showcases events in archaeological periods in Dolenjska, from the first few traces of humans in the Stone Age right through to the end of the early Middle Ages and the dense settlement of the area. Only five percent of rich and amazing archaeological heritage is presented on the exhibition while the rest is kept in our depositories. The introductory part of the exhibition presents the natural heritage of Dolenjska, complete with the major bedrocks and fossils. The main part of the exhibition, occupying three rooms, is devoted to the Early Iron Age. (Figure 5) The exhibition contains numerous high-quality, significant and attractive archaeological objects. Among the most important of these are bronze, figurally decorated situlae found in the cemeteries at Kandija and in Kapiteljska njiva in Novo mesto. (Figure 6) There is also an exceptional range of variously coloured glass beads, supplemented by amber and bronze jewellery. Testifying to the elaborate equipment of important figures in the Early Iron Age are the mass of bronze and iron weapons, including outstanding bronze helmets and bronze armour. The rich archaeological material on display in the permanent exhibition enhances our knowledge of life in the wider Dolenjska area from prehistory through to the early Middle Ages (Križ et al., 2009).

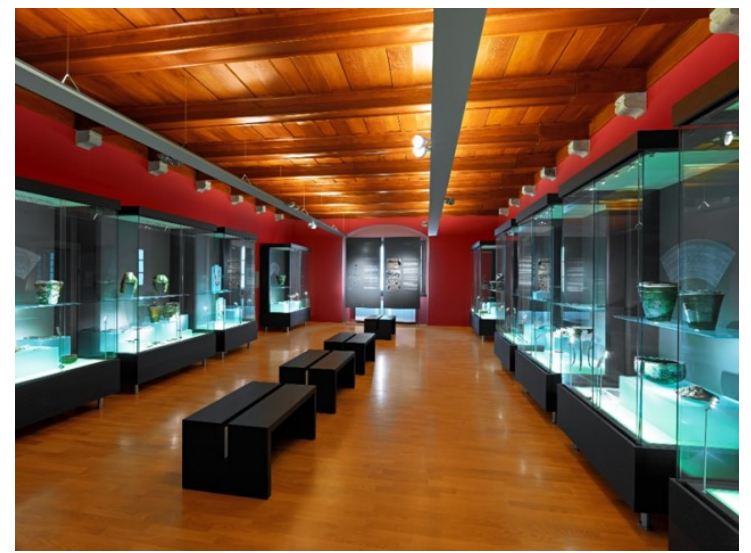

Figure 5. The main room on archaeological exhibition is dedicated to the richest princely graves of Hallstatt period. 


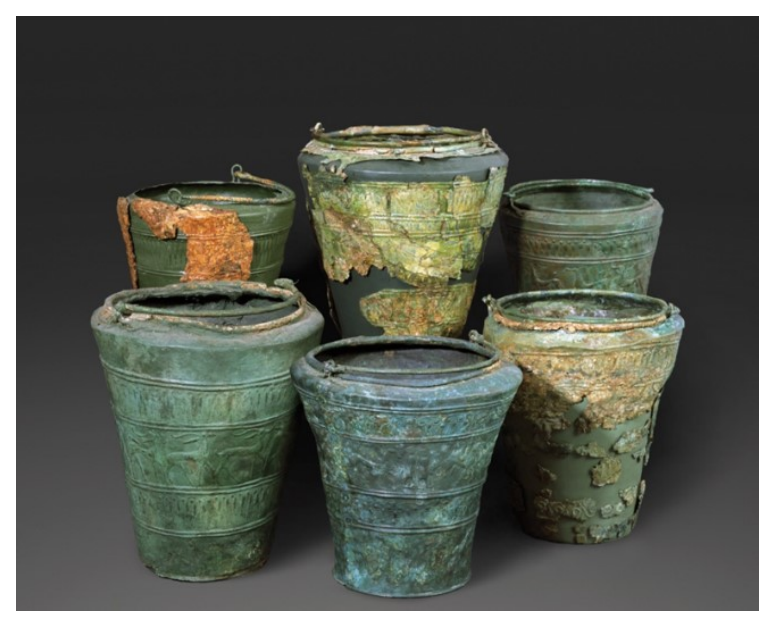

Figure 6. Figurally decorated bronze situlae from Novo mesto.

\section{Closer overview will be done on archaeological heritage from the Early Iron Age}

The Early Iron Age period was a time of prosperity, progress and blossoming of the whole society, which expressed its success in the cult of the dead by burying the deceased under the earthen barrows, which can be seen even today on the field. The upper classes of the socially ranked society are represented by the notables, who have been called Hallstatt princes by researchers. Rich and special grave goods were found in such princely graves.

Very sophisticated and artistic objects are bronze vessels called situlae. In the area of Slovenia, we have no written sources from the Early Iron Age but we have some scenes with human and animal figures curved in bronze sheet that can be read almost like a book. The archaeological excavations in Novo mesto that have taken place since 1890s until today have resulted in the discovery of sixteen bronze situlae, nine of which have been decorated in the figural Situla Art style (Križ, 2012). Bronze situlae in Novo mesto were found in graves with grave goods which date to the end of fifth and to the fourth century BC.

In the archaeological collection of Dolenjski muzej special point is put on huge amount of multicoloured glass beads of varied decorations and shapes (Figure 7).

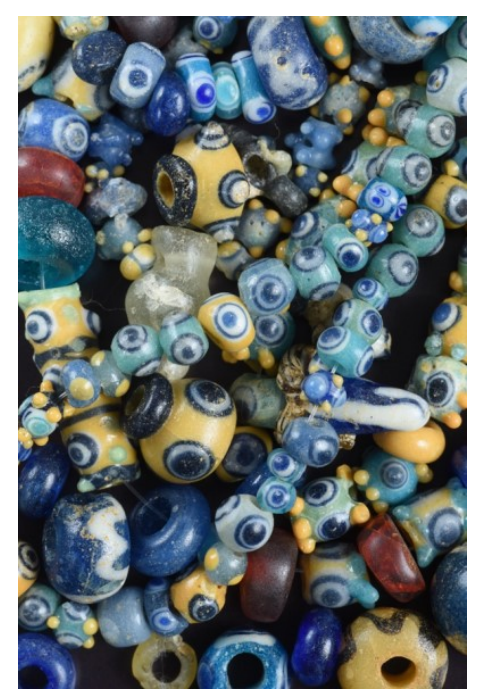

Figure 7. Multicoloured glass beads of necklace. Novo mesto, Kapiteljska njiva, various graves. 6th-4th century BC. 
Very often they are complemented by orange-red amber beads (Križ, 2017). In the Early Iron Age, the trade with amber increased greatly and it came on Dolenjska region by the Amber Road from the area of the Baltic coast (Figure 8).

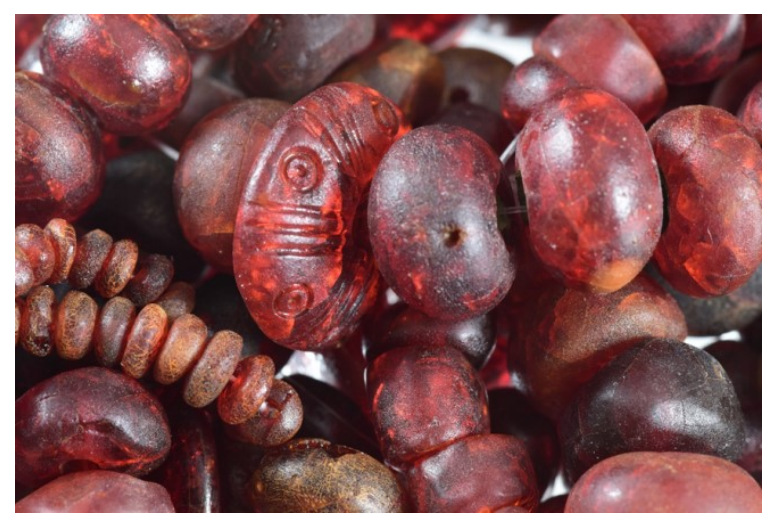

Figure 8. Amber bead necklaces from the Early Iron Age. Novo mesto, Kapiteljska njiva, various graves, \&th-4th century BC.

The impressive equipment of Early Iron Age chiefs is attested by the many bronze and iron weapons found, with bronze helmets and breastplates being particularly outstanding (Figure 9).

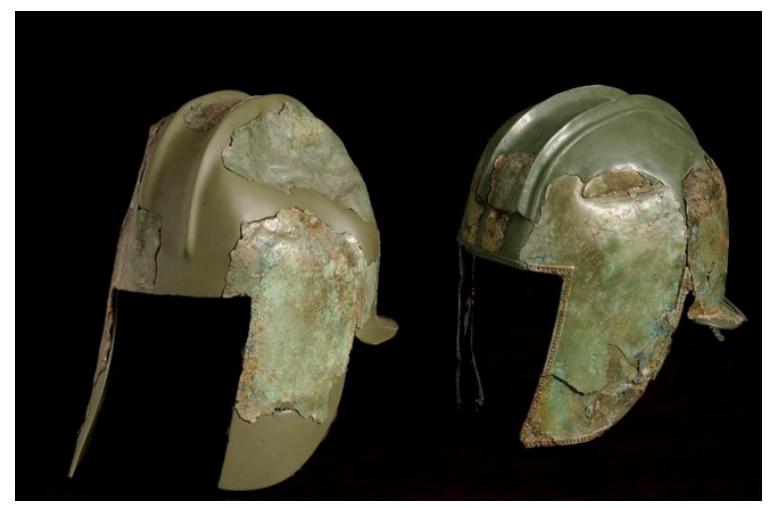

Figure 9. Grave VII/19 from Kapiteljska njiva is one of the most richly equipped graves in the South-eastern Alpine region. Two Greco-Illyrian helmets were in the grave. 5th-4th century BC.

\section{Fields of work}

Our professional work involves considerable collaboration with external institutions. We work together with the Chemical Institute in Ljubljana, the Institute of Archaeology at the Slovenian Academy of Arts and Science in Ljubljana, the Institute of Mediterranean Heritage, the National Museum of Slovenia, the archaeology departments at the Faculty of Arts in Ljubljana and in Zagreb, the restoration and conservation workshop at the Roman-Germanic central Museum in Mainz, and many similar institutions in Slovenia and abroad. We closely cooperate with the novo mesto regional unit of the heritage protection institute. We also regularly prepare popular and academic science article, lectures, and actively cooperate in international symposiums (Bregar et al., 2010).

Our special focus is also on filed work, especially for the last thirty years on the excavations at the Kapiteljska njiva site in Novo mesto (Figure 10). The systematic, annual archaeological research has produced excellent results that not only enrich our archaeological knowledge of Dolenjska and Slovenia in the first millennium BC, but also our knowledge of Europe as a whole in that epoch (Križ and Stipančić, 2016). 


\section{Conclusions}

Our work is not only to research, study and take care of the heritage. Our role is also to present and promote. To make archaeology more understandable and closer to our public. One of the projects how to closer our common heritage is Situlae Festival. Every year for the last six years we prepare it at the end of June. It is a festival of iron age life, cuisine and culture. With reconstructions, craftsmen, cuisine and music the town changes into a Hallsttat town (Figure 11). Our main work and role are to develop common consciousness of meaning of heritage, on which national identity is standing and to help growing museum public from the earliest time.

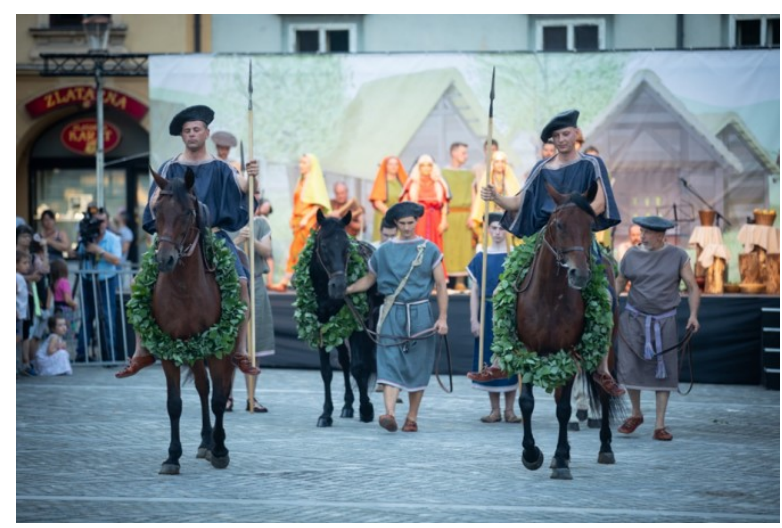

Figure 11. Scene from the Situlae Festival which is held at the end of June.

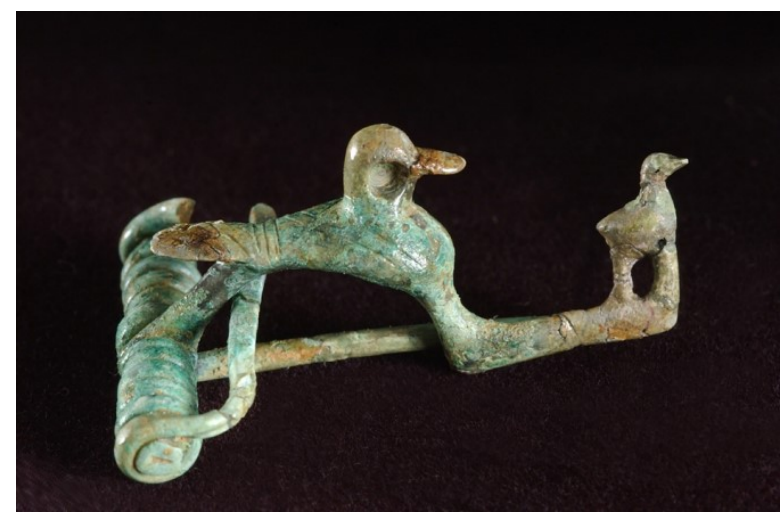

Figure 12. Bronze fibula with two ducks. Novo mesto, Kapiteljska njiva, Grave XVI/12. 6th century BC.

Acknowledgements: All photo images (Figure 1-12) are from archive of Dolenjski muzej Novo mesto. Conflicts of Interest: The authors declare no conflict of interest.

\section{References}

1. Bregar M, et al. 60 let Dolenjskega muzeja Novo mesto. Novo mesto. 2010.

2. Križ B. Reflections of Prehistory in Bronze. The Situla Art of Novo mesto. Novo mesto. 2012.

3. Križ B. Amber Jewels of the Baltic in Novo mesto. Catalogue of temporary exhibition. Novo mesto. 2017.

4. Križ B, Stipančić P, Škedelj Petrič A. Archaeological Image of Dolenjska. Catalogue of permanent exhibition. Novo mesto. 2009.

5. Križ B, Stipančić P. A thousand-year necropolis. Catalogue of temporary exhibition. Novo mesto. 2016. 